\title{
graduate.id: A Business Model to Cater the Needs of Graduates on Graduation Ceremony
}

\author{
Dita Yuniar ${ }^{1}$ Arif Imam Suroso ${ }^{1}$ Febriantina Dewi $^{1}$
}

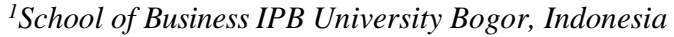 \\ Corresponding Author E-mail: yuniardita48@gmail.com
}

\begin{abstract}
Graduation ceremony, especially from higher education institutions, is a cause for celebration in Indonesia, where graduates and their family will dress to the teeth and have their photo taken by professional photographer. Therefore, there is high demand for clothes, accessories, professional make-up artist and professional photo service. However, there is no marketplace that cater to the specific need for graduation ceremony. This research aims to identify customers problems related to preparing for their graduation ceremony, to design product that provide solutions for those problems and to develop business model for the product. This research use design thinking for making product prototype and business model canvas to design the business model. We develop graduate.id, e-marketplace specialized for graduation ceremony related needs. There are two iterations of product prototype and business model canvas. The proposed values of graduate.id are try at home feature, reputable vendors, product exchange warrantee, choices of products and services, graduation references and bidding feature.
\end{abstract}

Keywords—business model canvas, design thinking, graduation ceremony, prototype

\section{INTRODUCTION}

Graduation ceremony is cause of celebration in Indonesia. In 2018, there were 1,247,116 graduates, where for 88.4 percent of them, it is the first graduation ceremony they participated in [12].

Graduation ceremony is a big deal, where graduates and their family will dress to the teeth. It is common for female graduates to wear national dress of kebaya underneath their graduation gown and have their hair and make-up done professionally. Male graduates usually wear suit and tie underneath their graduation gown.

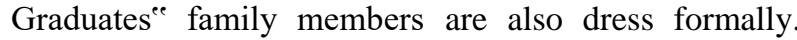
Before or after graduation ceremony, it is common for the whole family to have their photo taken professionally in a photo studio to commemorate this joyous occasion.

The needs related to graduation ceremony opens up a new business venture, where all providers related to graduation ceremony are listed on a marketplace, especially an e-marketplace. Indonesian are familiar with e-commerce, with US \$ 21 billion in transaction value in 2019 [1][8]. The existing e-commerce offers general products [7], not catered specifically for offering graduation ceremony related products. Therefore, this research is exploiting the possibility of creating an emarketplace, that specifically cater to graduate ceremony related products, so it is more convenient for the proposed customers to find all goods and

services needed for their big day. Equipment that they needed through various media, even physical stores directly.

The aims of this research are to identify customer problems related to preparing for their graduation ceremony, to design products that provide solution for those problems and to develop a business model of it.

\section{METHODS}

Data collected by in depth interview and survey to the proposed customer segment. Respondents are chosen in a non-probability sampling, purposive and snowball.

Design thinking method is used. Design thinking is a comprehensive customer-oriented innovation approach that aims to generate and develop creative business ideas or entire business models [3]. There are five stages in this method, which were empathize, define, ideate, prototype and test [5]. In this research, improvement stage is added after test stage.

\section{A. Empathize}

Empathize is the stage to help researchers to understand what customers" sees, feels, and experiences. In this research, empathize stage is done to identify customers" problems when preparing their graduation ceremony. In depth interviews is used deeply explore customers" experiences, feelings, and perspectives [9]. In depth interview is done with 51 respondents, 15 male and 36 female respondents. They are graduates of year 2018, 2019, and 2020 from IPB University, Pakuan University, Djuanda University, Analytical Chemistry Academy and Midwifery Program of Bandung Nursing Polytechnique.

\section{B. Define}

Define is the stage to frame customers" problem found at empathy in an empathy map. According to Purwantono and Suwandi [10], empathy map strongly supports the design of business model because it can understamd customers experience that relates to value propositions element in business model canvas. 


\section{Ideate}

Ideate is the stage to create ideas to for solutions to customers" problems. The solutions are developed into business model canvas. Business model canvas helps researchers describing what organization need to do in order to be able to creates, delivers, and captures values for intended customers [2].Prototype

At this stage, researchers visualize and transform the solutions into a physical system that can be used and tested. Prototype is an initial model that shows the functions of a system that built [11]. In this stage, an experimental system is built rapidly and economically, so the proposed solutions can be evaluated by proposed customers to get their feedback.

On this research, we build an initial model of mobile application. Prototype was made by identifying the system requirement using use case diagram to illustrate the functions that users can do in the system to find system"s boundaries [4].

\section{Test}

Test is a process to evaluate the prototype by getting customers feedback. The test was done using user experience questionnaire (UEQ) [6] in a 1 to 5 rating, where 1 means strongly disagree and 5 means strongly agree. The questionnaire was answered by 38 respondents, 23 potential respondents from empathize stage and 15 new respondents who share the same characteristics with targeted customer.

\section{E. Improvement}

Feedback from the test stage is used to improve the prototype.

\section{RESULTS}

\section{A. Empathize}

Respondents" characteristics is shown in Table 1.

TABLE 1. RESPONDENTS" CHARACTERISTIC

\begin{tabular}{|c|c|c|c|}
\hline \multicolumn{2}{|c|}{ Respondent characteristic } & Total & Percentage \\
\hline \multirow{2}{*}{ Gender } & Male & 15 & 29.4 \\
\hline & Female & 36 & 70.6 \\
\hline \multirow{5}{*}{ Colleges } & IPB University & 24 & 47.1 \\
\hline & Pakuan University & 15 & 29.4 \\
\hline & $\begin{array}{l}\text { Analytical } \quad \text { Chemistry } \\
\text { Academy }\end{array}$ & 9 & 17.7 \\
\hline & Djuanda University & 2 & 3.9 \\
\hline & $\begin{array}{l}\text { Midwifery Program of } \\
\text { Bandung Nursing Academy }\end{array}$ & 1 & 1.9 \\
\hline \multirow{2}{*}{ Degree } & Bachelor of Science & 38 & 74.5 \\
\hline & Applied Science Diploma & 13 & 25.5 \\
\hline \multirow{3}{*}{$\begin{array}{l}\text { Graduation } \\
\text { year }\end{array}$} & 2020 & 12 & 23.5 \\
\hline & 2019 & 29 & 56.9 \\
\hline & 2018 & 10 & 19.6 \\
\hline \multirow{4}{*}{$\begin{array}{l}\text { Average } \\
\text { Bxpendesine } \\
\text { per month } \\
\text { before } \\
\text { graduation }\end{array}$} & $<$ Rp1 000000 & 15 & 29.4 \\
\hline & Rp1 000 001-Rp2 000000 & 17 & 33.3 \\
\hline & Rp2 000 001-Rp3 000000 & 15 & 29.4 \\
\hline & Rp3 000 001-Rp4 000000 & 4 & 7.9 \\
\hline
\end{tabular}

The empathize stage shows that male and female graduates have different problems to prepare for their graduation ceremony. For male graduates, dressing up for graduation ceremony is not that difficult. They do not see the need for new fashion items nor the need for make-up artist or get their photo taken in a photo studio. Fig. 1 shows empathy map of male graduates.

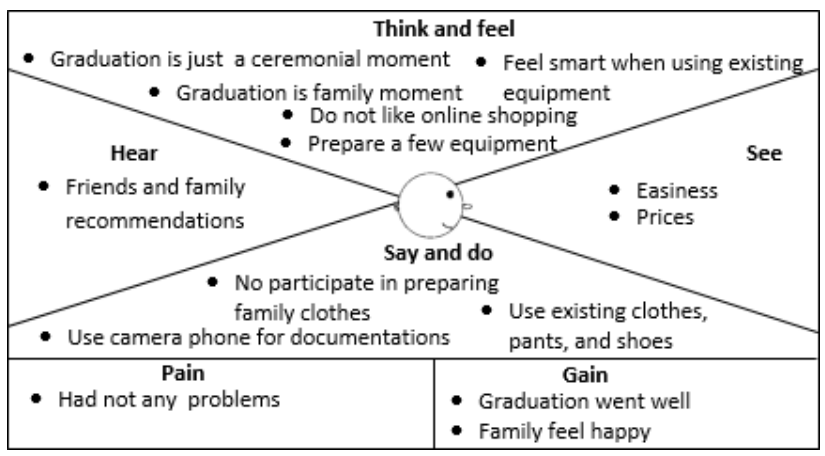

Fig. 1. Empathy map of male graduates

Unlike their male counterparts, female graduates feel the need to dress to the teeth, almost similar with dressing up for their wedding. Female graduates need new kebaya, make-up artist, hair or hijab do and photo studio. They also feel the need to dress their family up for professional looking photo.

Female graduates have difficulty to fulfill all these needs. They do not have information on good make-up artist or fail to book professional photographer and photo studio. They do not have information on good vendors that can cater to their needs. There is no one stop place where they can find all the vendors that they need. Thirty-two respondents like online shopping, but only nine respondents that get some of their needs via online shopping. They hesitant to fulfill those needs because the products available is not considered good enough. Good kebaya is made to order. Fig. 2 shows empathy map of female graduates.

\begin{tabular}{|c|c|}
\hline $\begin{array}{l}\text { - Book make up artists } \\
\text { - Book studio photo or professional } \\
\text { photographer }\end{array}$ & $\begin{array}{l}\text { Graduation is a symbol of completing } \\
\text { study, family moment, and special } \\
\text { moment like wedding } \\
\text { to dress } \\
\text { Match each products and compare } \\
\text { orices }\end{array}$ \\
\hline 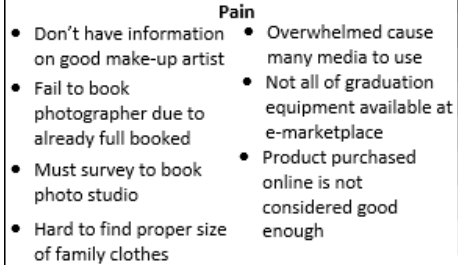 & $\begin{array}{l}\text { Gain } \\
\text { - Easier and faster to prepare graduation } \\
\text { equipment } \\
\text { - Products purchased online as expected } \\
\text { - Easy to find family clothes with the } \\
\text { proper size } \\
\text { - Easy to book suitable make up artist, } \\
\text { photgrapher and photo studio }\end{array}$ \\
\hline
\end{tabular}

Fig. 2. Empathy map of female graduates 


\section{Ideate}

We develop graduate.id as the solution based on female graduates ${ }^{e c}$ problems It is an e-marketplace specialized to

cater all those needs for graduation ceremony. The business model canvas of graduate.id is:

\section{Customer segments}

The customer segment is defined as middle-andupper class female, first time graduates and like online shopping.

\section{Value propositions}

The proposed values are to provide one stop market place for clothing -such as kebaya or synchronized formal outfit for the whole family-, shoes, hijab or hair do, makeup artists, photographers, and photo studios. Graduate.id provides try at home feature that allow customers to try cloths and shoes, star vendor" that assuring them to get superb services and product exchange warrantee that allow customers to exchange product that not up to their standards. graduate.id provide a place where vendors all over the country can meet their customers. The main vendors featured are make-up artist, photographer and photo studio. They also provide tips on the latest trends.

\section{Channels}

The channels are mobile applications store and social media.

\section{Customer relationships}

graduate.id will provide vouchers through in social media and provide, ,share for point ${ }^{\mathrm{ec}}$ feature to encourage customers to share information about graduate.id to their friends and family. All vendors featured must agree on providing certain standard level of service.

\section{Revenue streams}

Revenue comes agreed upon percentage of every transaction value on graduate.id.

\section{Key resources} tech

The key resource is ICT and human capital to run the

\section{Key activities}

Key activity is vendor selection. Selection is based on vendor portfolio that contains information on business profile, product (goods and services) sample photo, physical store and social media handle.

\section{Key partnerships}

The key partners are vendors and delivery service providers.

\section{Cost structures}

The main costs are mobile application development and maintenance application, marketing and operational cost. Fig. 3 shows the first iteration of business model canvas of graduate.id.

\begin{tabular}{|c|c|c|c|c|c|c|}
\hline $\begin{array}{l}\text { Key Partnerships } \\
\text { Vendors: } \\
\text { - Sellers of } \\
\text { graduation } \\
\text { clothes, shoes, } \\
\text { hijab } \\
\text { - Make-up } \\
\text { artists, } \\
\text { photographers } \\
\text { photo studios } \\
\text { Delivery service } \\
\text { providers }\end{array}$ & $\begin{array}{l}\text { Key Resources } \\
- \text { ICT } \\
\text { - Human } \\
\text { capital }\end{array}$ & \multicolumn{3}{|c|}{$\begin{array}{l}\text { Value proposition } \\
\text { - One stop } \\
\text { marketplace for } \\
\text { graduation } \\
\text { ceremony } \\
\text { - Try at home } \\
\text { feature } \\
\text { - Star vendors } \\
\text { - Product } \\
\text { exchange } \\
\text { warrantee } \\
\text { - Latest fashion } \\
\text { trends }\end{array}$} & $\begin{array}{l}\text { Customer } \\
\text { Relatioships } \\
\text { - Promotion } \\
\text { in social } \\
\text { media } \\
\text { - Vouchers } \\
\text { - Share for } \\
\text { point } \\
\text { - SOP of } \\
\text { services }\end{array}$ & $\begin{array}{l}\text { Customer segments } \\
\text { - Middle-and- } \\
\text { upper class } \\
\text { female } \\
\text { - First time } \\
\text { graduates } \\
\text { - Like online } \\
\text { shopping }\end{array}$ \\
\hline \multicolumn{4}{|c|}{$\begin{array}{l}\text { Cost Structure } \\
\text { - Development and maintenance } \\
\text { application } \\
\text { - Marketing } \\
\text { - Operational }\end{array}$} & \multicolumn{3}{|c|}{$\begin{array}{l}\text { Revenue Streams } \\
\text { - Percentage of every transactions }\end{array}$} \\
\hline
\end{tabular}

\section{Prototype}

graduate.id is a mobile-application based emarketplace that. Fig. 4 shows the functions available at graduate.id mobile application.

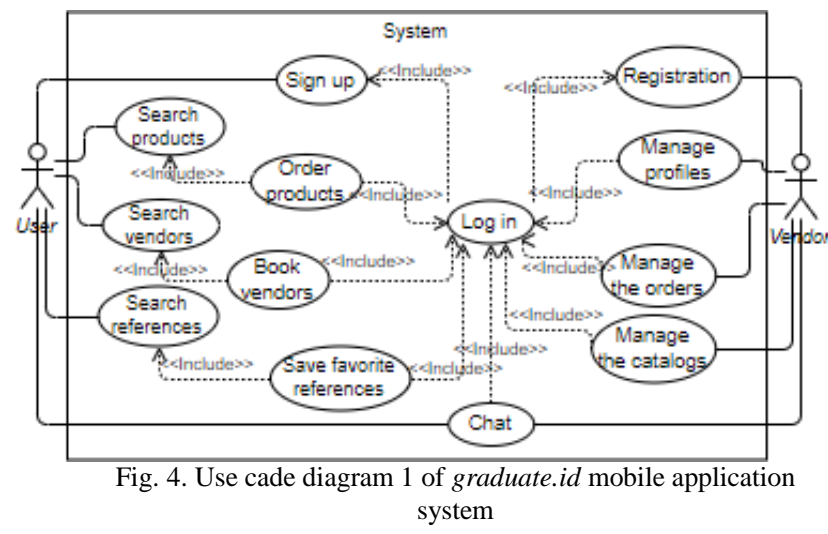

All functions on this system is available on the first prototype that available at https://marvelapp.com/acc185b or by scanning the QR code in Fig. 5.

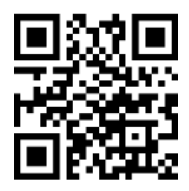

Fig. 5. QR code of graduate.id first prototype

\section{E. Test}

First prototype testing is done by user experience questionnaire that includes four assessment variables of value, usability, desirability, and adoptability. Value shows harmony of product features with customers" needs, usability measures how easily the customers use the product, desirability shows customers" emotional appeal, and adoptability shows ease to access the product [6]. Fig. 6 shows the test result. 


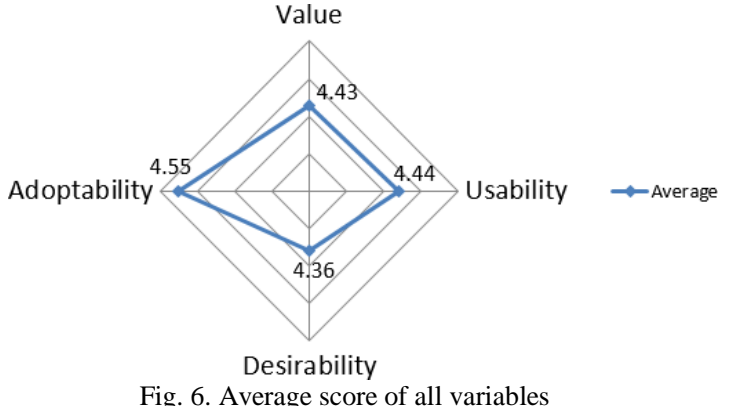

Fig. 6. Average score of all variables

All of user experience variables shows high average test scores; 4.43 for value, 4.44 for usability, 4.36 for desirability, and 4.55 for adoptability on 1 to 5 scales; that indicates respondents" satisfaction on the concept and features of graduate.id.

\section{Value}

Values of graduate.id include four variables seen in Fig.

7.

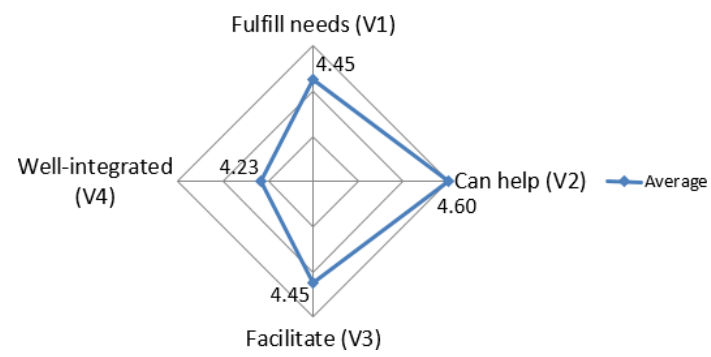

Fig. 7. Average score of value variables

The features of graduate.id can help, facilitate, and fulfill needs of customers. The average scores for V1, V2, and V3 are 4.45, 4.60, and 4.45 respectively. However, V4 has lower average score, which is 4.23 that shows the functions of prototype 1 is not well integrated. The customer feedback on value variables are detailed at Table 2.

TABLE 2. RESPONDENTS" FEEDBACK ON VALUE VARIABLES

\begin{tabular}{|c|c|c|}
\hline $\begin{array}{l}\text { Respondent } \\
\text { ID }\end{array}$ & Perceived Weakness & Suggestion \\
\hline $\begin{array}{l}3,9,21,22, \\
36\end{array}$ & Lack of prices variation & Add bid feature \\
\hline $\begin{array}{l}5,9,11,19, \\
20,29,31, \\
32,34\end{array}$ & $\begin{array}{l}\text { Lack of product } \\
\text { categories variances }\end{array}$ & $\begin{array}{l}\text { Add more product } \\
\text { categories such as bags, } \\
\text { accessories, custom } \\
\text { kebaya, and syar'i } \\
\text { kebaya }\end{array}$ \\
\hline 17,22 & Lack of tips & $\begin{array}{l}\text { Provide tips for make- } \\
\text { up trends and tutorials }\end{array}$ \\
\hline
\end{tabular}

According to Erlyana and Hartono [14], product variations is a strength value of an e-marketplace. It can give customers freedom to find proposed products and services. However, this value was still not met by graduate.id first prototype.

\section{Usability}

The average scores for usability variables are shown on Fig. 8.

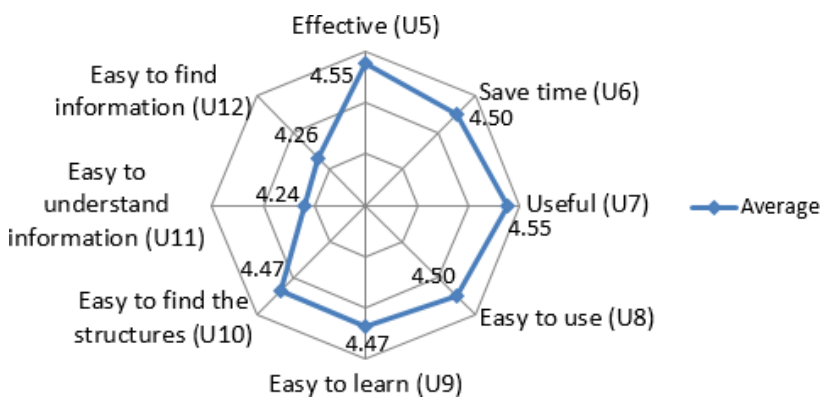

Fig. 8. Average scores of usability variables

graduate.id considered useful by customers on effectivity and time efficiency. Variables of „easy to use", "easy to learn" and "easy to find" scores high. Nevertheless, there are average scores on V11 and V12 where the first prototype is perceived as ,information is not easy to find"and ,available information is not easy to understand". There is lack of detail on available information and lack of specificity on the search feature. The details are shown on Table 3 .

TABLE 3. RESPONDENTS" FEEDBACK OF USABILITY VARIABLE

\begin{tabular}{|l|l|l|}
\hline $\begin{array}{c}\text { Respondent } \\
\text { ID }\end{array}$ & \multicolumn{1}{|c|}{$\begin{array}{c}\text { Perceived } \\
\text { Weaknesses }\end{array}$} & \multicolumn{1}{c|}{ Suggestion } \\
\hline $3,19,26,34$ & Lack of detail & $\begin{array}{l}\text {-Provide information about the part } \\
\text { of product sold } \\
\text {-Provide description of the variants } \\
\text { and size of product on the model } \\
\text { - Provide photos of products from } \\
\text { multiple vantage points }\end{array}$ \\
\hline 16,37 & $\begin{array}{l}\text { Lack of } \\
\text { specificity }\end{array}$ & $\begin{array}{l}\text {-Adjustment of search feature } \\
\text {-Location based vendor finder }\end{array}$ \\
\hline 18,34 & & $\begin{array}{l}\text {-Allow the use of Google or } \\
\text { Facebook account for sign up and } \\
\text { log in }\end{array}$ \\
\hline & & \\
\hline
\end{tabular}

\section{Desirability}

The average score of desirability variables shown on Fig. 9.

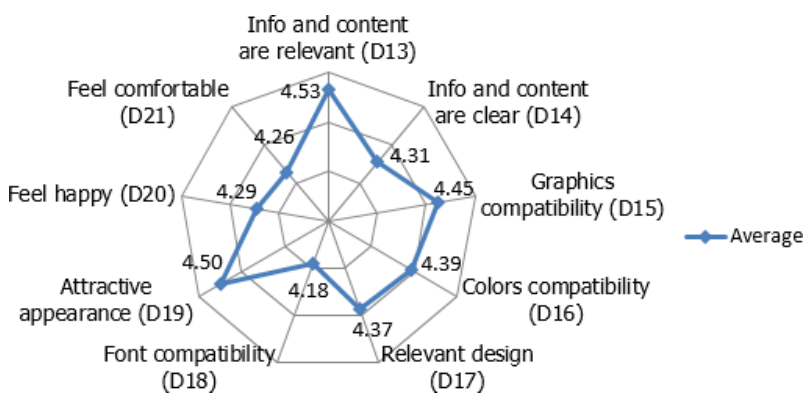

Fig. 9. Average score of desirability variables

Desirability has lowest average score. Four variables of this factor have low average scores. Variables D14, D18, D20, and D21 scores are 4.31, 4.18, 4.29, and 4.26 respectively. The details are shown on Table 4 . Because the

font choice used on the first prototype is perceived as too small, so customers cannot read the information clearly. The interface design is perceived as too tight and too crowded, so it makes customers feel uncomfortable. 
TABLE 4. RESPONDENTS" FEEDBACK OF DESIRABILITY VARIABLES

\begin{tabular}{|c|l|l|}
\hline $\begin{array}{c}\text { Respondent } \\
\text { ID }\end{array}$ & \multicolumn{1}{c|}{ Perceived Weakness } & \multicolumn{1}{c|}{ Suggestion } \\
\hline $\begin{array}{c}4,7,8,17, \\
28,30,31\end{array}$ & $\begin{array}{l}\text {-The font size is too small } \\
\text {-The information is hard to } \\
\text { read }\end{array}$ & $\begin{array}{l}\text { Change font type and } \\
\text { size }\end{array}$ \\
\hline $\begin{array}{c}\text { rea } 15,17,20,2 \\
3,26,27\end{array}$ & $\begin{array}{l}\text { The interface design is too } \\
\text { tight and too crowded }\end{array}$ & $\begin{array}{l}\text { Make minimalist and } \\
\text { unique design }\end{array}$ \\
\hline
\end{tabular}

\section{Adoptability}

Respondents feel that graduate.id is easy to find on mobile application store, with average score of 4.55 . Mobile application based is considered suitable for graduate.id.

In line with the study of Munthe et al [13], the most important user experience element for user in using a mobile application are product's functionality, product's features, easy to access, learnability, findability, and readability. From the test result, graduate.id first prototype still has weaknesses in some of these elements.

\section{F. Improvement}

Improvements are made on prototype and business model canvas. Fig. 10 shows the improved business model canvas.

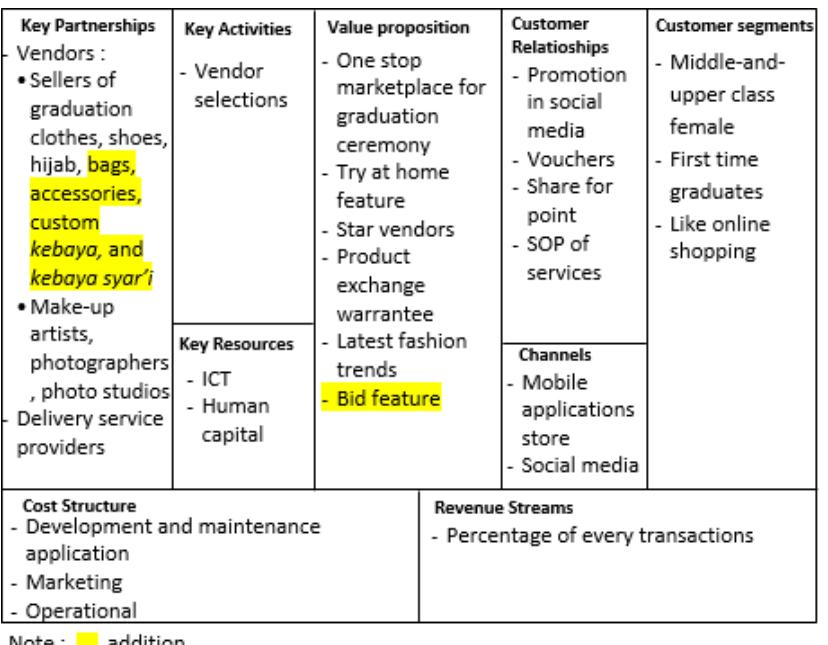

Fig. 10. Second iteration of graduate.id business model canvas

Improvements also made on the prototype"s function, features, contents and appearance. Fig. 11 shows second iteration of use case diagram of graduate.id system.

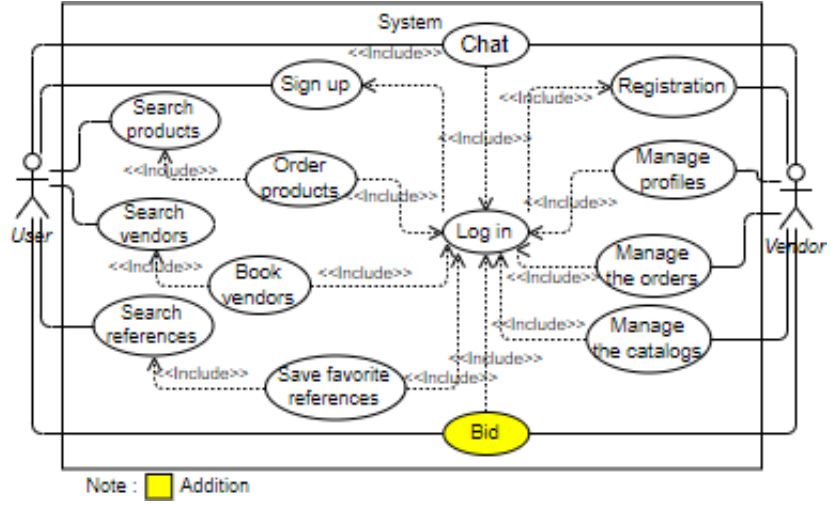

Fig. 11. Use case diagram 2 of graduate.id system

The new and improved prototype is available at https://marvelapp.com/22g $4501 \mathrm{~g}$ or by scan the QR code on Fig. 12.

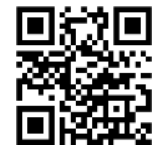

Fig. 12. QR code of graduate.id second prototype

\section{CONCLUSIONS}

Female graduates have difficulty to fulfill all graduation ceremony related needs. They do not have information on good make-up artist or fail to book professional photographer and photo studio. They do not have information on good vendors that can cater to their needs. We develop graduate.id to solve customers" problems. graduate.id is an e-marketplace that connect customers with goods and services providers. graduate.id provides ,try at home", „star vendors", "product exchange warrantee" „latest fashion trends", and "bid feature".

Future build is graduate.id Pro for goods and service providers with features that will cater to their needs of providing prime goods and services.

\section{REFERENCES}

[1] [APJII] Asosiasi Penyelenggara Jasa Internet Indonesia, Penetrasi \& Perilaku Pengguna Internet Indonesia Survey 2017, 2017.

[2] A. Osterwalder, and Y. Pigneur, Business Model Generation, New Jersey: John Wiley \& Sons In, 2010.

[3] C.M Roterberg, Handbook of Design Thinking: Tips \& Tools For How To Design Thinking, 2018.

[4] C. Larman, Applying UML and Patterns, 2005.

[5] [d.school] Institute of Design at Stanford, Bootcamp Bootleg, 2013.

[6] F. Guo, More than usability: The Four elements of User Experience, [Internet], available at : http://www.uxmatters.com/mt/archives/2 012/04/more-thanusability-the-fourelements-of-user-experience- part-i.php, 2012.

[7] G. S. Budhi, "Analisis Sistem E-Commerce pada Perusahaan Jual- Beli Online Lazada Indonesia," ELINVO, vol.1, pp. 78-82, 2016.

[8] Google and Temasek, e-Conomy SEA 2019, 2019 
[9] H.S. Minhat, "An overview on the methods of interviews in qualitative research," IJPHCS, vol. 2, pp. 210-2014, 2015.

[10] I. Purwantono, and Suwandi, "Rencana Bisnis Kuliner Bebek Blengong di Jakarta”, JEMI, vol. 2, pp. 109-114, 2019.

[11] K.C Laudon, and J.P Laudon, Management Information Systems Managing the Digital Firm, New York : Pearson, 2018.

[12] [PDdikti] Pusat Data dan Informasi Ilmu Pengetahuan, Teknologi, dan Pendidikan Tinggi, Statistik Pendidikan Tinggi 2018, Jakarta: Kemenristekdikti, 2018.

[13] R. D Munthe, K. C. Brata, and L. Fanani, "Analisis User Experience Aplikasi Monile Facebook", JPTIIK, Vol. 2, pp. 2679$2688,2018$.

[14] Y. Erlyana and H. Hartono, "Business model in marketplace industry using business model canvas approach: An e-commerce case study", 2017 